\title{
O PERÍODO É UMA CONSTRUTURA
}

\author{
The period is a constructure
}

\author{
Carlos Alberto Faraco
}

\begin{abstract}
RESUMO
A Gramática Construtural é uma teoria gramatical desenvolvida durante os anos 60 que oferecia, grosso modo, uma análise de constituintes imediatos com a possibilidade de pular fronteiras para cima ou para baixo; e uma análise da estrutura com base numa grande relação de dependência, ou seja, a estrutura entendida como um conjunto de elementos em dependência com um deles. A Gramática Construtural nos prometia o paraíso. Foi, por isso, duramente criticada. Contudo, até onde sei, seus pressupostos gerais e suas análises pontuais nunca foram objeto de crítica sistemática. Quando ela veio a público, vivia-se já sob outros referenciais epistemológicos e ela foi descartada in limine pelo mundo acadêmico.
\end{abstract}

Palavras-chave: análise construtural; período gramatical; sintaxe.

\begin{abstract}
Constructural Grammar is a grammatical theory developed during the nineteen sixties which, roughly speaking, offered an analysis of immediate constituents with the possibility of skipping boundaries up or down; as well as an analysis of the structure based upon a major dependence relation, i.e. the structure understood as a set of elements in dependence to one of them. Constructural Grammar promised us heaven, so to speak, reason why it was so harshly criticized. However, to the best of my knowledge, its general assumptions and its specific analyses have never been subject to systematic review. When it became public, linguists were already under other

* Professor aposentado da UFPR.
\end{abstract}


epistemological frameworks, and Constructural Grammar was dismissed in limine by the academic community.

Keywords: Constructural analysis; grammatical period; syntax.

Quando cheguei no curso de Letras e, já no primeiro ano, fui aluno do Professor Eurico Back em Linguística e Língua Portuguesa, eu vinha de um curso secundário (ginásio e colégio) de muito boa qualidade. Em Português especificamente, o centro do currículo haviam sido as práticas de linguagem: a leitura, a produção de texto e as atividades da oralidade (exposições, declamações, debates, polêmicas civilizadas). 0 estudo gramatical (morfologia e sintaxe) era realizado sistematicamente, mas ocupava, de fato, um segundo plano. As questões normativas eram trabalhadas em conexão com as práticas de linguagem.

Dessa experiência escolar saí com um domínio razoável da escrita e da fala em público; com balizas normativas bastante realistas (meus professores distinguiam com clareza o obrigatório do optativo e o real do inventado); e com um bom conhecimento do saber gramatical tradicional um saber que não só me dava instrumentos para uma reflexão básica sobre o funcionamento estrutural da língua, mas me dava também grande prazer intelectual. Os exercícios de análise sintática me davam tanta satisfação quanto a demonstração de teoremas e os exercícios de cálculo aritmético ou algébrico.

Por isso, ao concluir o ensino médio, me achava muito sabedor de sintaxe, da sintaxe que meus professores do curso secundário não qualificavam - era só sintaxe.

Talvez minha experiência universitária tenha começado justamente quando vim a saber que essa sintaxe era qualificada de "tradicional" e merecia todo o desdém do meu professor de Linguística e Língua Portuguesa do primeiro ano de Letras. Logo nas primeiras aulas ele nos dizia que era preciso desligar-se de todo o conhecimento gramatical anterior, que era preciso recomeçar do zero.

Sugeria até que nos desfizéssemos de gramáticas ("tradicionais") que eventualmente tivéssemos conosco. E justificava essa atitude iconoclasta com argumentos (convincentes) que apontavam as limitações empíricas e as inconsistências dos conceitos e dos fundamentos do saber tradicional.

Em resumo, no primeiro ano de Letras, meu mundo gramatical caiu. Quem se achava muito sabedor de sintaxe se viu, de repente, nu no meio da praça. Mas não completamente perdido porque seduzido pela força retórica de um discurso que nos convidava a pensar a linguagem cientificamente e nos prometia uma análise rigorosamente consistente dos fatos linguísticos que nos levaria a uma descrição perfeita e integral da língua. 
E as demonstrações teóricas e analíticas que iam se sucedendo pareciam, de fato, irretocáveis. O sintaticista que havia em mim voltou a mergulhar com ânimo e prazer agora no estudo dos níveis construturais: seus elementos constitutivos; a grande relação estruturante que atravessava todos os níveis - qual seja, a existência de um elemento independente, que podia realizar sozinho o nível sintático de que era constituinte, e o(s) eventua(is) elemento(s) dele dependente(s), fixados os dois conjuntos na figura do sol e do(s) planeta(s) sintático(s) -; e os processos de promoção e subordinação pelos quais estruturas de nível superior podiam ocorrer como constituintes de níveis inferiores (subordinação a) e estruturas de nível inferior podiam ocorrer como constituintes de níveis superiores (promoção a).

Em outros termos, uma análise de constituintes imediatos com a possibilidade de pular fronteiras para cima ou para baixo; e uma análise da estrutura com base numa grande relação de dependência, ou seja, a estrutura entendida como um conjunto de elementos em dependência com um deles.

E ainda mais: por ser proibido, no estudo da sintaxe (no estudo do significante), utilizar critérios semânticos, a análise se sustentava na prosódia como recurso para identificar os segmentos constitutivos dos diferentes níveis.

Nesse sentido, tinham particular relevância a entoação e a intensidade. A primeira, chamada de altura, era o ponto de referência para distinguir os diferentes tipos de períodos (o que se fazia por meio de um jogo com 4 tons: tom constante 3 e tom final 4 ascendente, período optativo; tom inicial 4 e final descendente, período interrogativo; tom constante 4 com final descendente, período jussivo; e tom inicial 3 e final 1 descendente, período assertivo).

A segunda servia de referência para delimitar as estruturas inferiores ao período (intensidade simples, vocábulo; intensidade dupla, locução; intensidade tríplice, sentença).

Havia aí, portanto, um empiricismo forte (nada de estruturas acima ou abaixo da superfície), uma dose curta de metafísica (pelo menos na sintaxe) e uma graciosa e razoavelmente azeitada máquina descritivo-estruturalista. Isso tudo, à época, me convencia e fascinava.

Se, depois, as coisas se complicaram, devo reconhecer que o modelo analítico construtural (aqui muito resumido) teve para mim pelo menos dois grandes efeitos. Primeiro, ampliou bastante o meu horizonte de observação do funcionamento sintático da língua: me convenci, de fato, das limitações do modelo tradicional (embora, apesar de todas as críticas, ele continuasse ainda, para várias coisas, produtivo para mim no raciocínio prático informal) e aprendi a dar atenção a fatores - como a prosódia - que me escapavam anteriormente. 
E, segundo, me obrigou a um interessante exercício de reordenamento dos dados do saber tradicional (fui percebendo que não era exatamente o caso de me desligar completamente do saber gramatical anterior, mas de pensar os mesmos fenômenos sob outro viés).

Ele cumprimentou quem chegou - "quem chegou" não era mais uma oração subordinada substantiva objetiva direta, mas um período interrogativo subordinado à locução e ocupando a posição 3 da sentença. Ou seja, uma classificação diversa com base num modelo outro, mas, no fundo, o mesmo fenômeno - a complementação do verbo por uma oração.

$E$ alguns desses reordenamentos eram algo impactantes. Por exemplo, a inversão do raciocínio no estudo dos vocábulos derivados, ou seja, considerar os sufixos derivacionais não como um elemento mórfico que se agrega a uma raiz para formar um novo vocábulo, mas, ao contrário, como um elemento mórfico nuclear (um "sol") a que se agrega um outro vocábulo (que funciona, então, como "planeta"). Diz a Gramática construtural:

Pobreza e gordura são dois substantivos e cada qual tem dois morfemas

pobre X eza;

gordo X ura.

Nestes dois substantivos, encontramos as raízes adjetivas pobre e gordo. Os dois vocábulos são substantivos por causa de /=eza/ e /=ura/. Chegamos à conclusão de que os eixos [termo que designa o sol do vocábulo] destes dois vocábulos são respectivamente /=eza/ e /=ura/. No sol de uma locução substantiva (núcleo) encontramos um substantivo; no sol de um substantivo (eixo) devemos encontrar uma raiz substantiva (BACK; MATTOS, 1972, v. I, p. 362).

Mas, certamente, a análise que mais me atraiu foi a do período.

No projeto construtural, havia uma nova nomenclatura e também um aproveitamento de termos tradicionais com outro conceitual. Assim, período é, grosso modo, a cadeia fônica proferida quer pelo emissor, quer pelo receptor (lembrando que o ponto de partida da análise construtural é o evento de comunicação em que emissor e receptor trocam cadeias fônicas). Nesta perspectiva, o período é o constituinte do nível cláusula. Corresponderia, em boa parte, ao que nos acostumamos a chamar, tempos depois, de enunciado.

o período por sua vez, como nível sintático em si, é entendido como um conjunto de uma ou mais sentenças. O termo "sentença" também não deve nos confundir: na análise construtural ele designa a cadeia fônica assinalada pela intensidade 3 sobre sua última sílaba forte. É, portanto, um segmento recortado com base na prosódia e não coincide necessariamente com a sentença tradicional, pensada como o segmento que tem sujeito e predicado e, no predicado, um verbo ou locução verbal. 
O nível sentença, constituinte do nível período, inclui, assim, as sentenças tradicionais, mas também muitas outras possibilidades estruturais, como podemos ler na Gramática (BACK; MATTOS, 1972, v. I, p. 136, 140), donde retiro alguns exemplos para efeitos de argumento:

- períodos mínimos (compostos de uma só sentença)
a) "O sol da tarde doura os campos."
b) "Primo do Silvino??"
c) "Qual nada!"
d) "Cuidado com o javanês!"

- períodos complexos (compostos de duas ou mais sentenças)

a) "Casa de ferreiro, espeto de pau."

b) "Bom dia, Carlos!"

c) "Leonora chegou-se para mim, a carinha mais limpa deste mundo."

d) "Se tinha de fugir, para que veio?"

e) "Projeto e construção, de quem?"

f) "Além do mais, como tu sabes, gosto de solidão."

Assumia-se que cada um dos segmentos desses períodos estava claramente delimitado pela intensidade tríplice sobre sua última sílaba forte, como grafado abaixo:

a) Casa de fe"'rreiro, espeto de "'pau.

b) Bom "'dia, "'Carlos!

c) Leonora chegou-se para "'mim, a carinha mais limpa deste "'mundo.

d) Se tinha de fu'"'gir, para que "'veio?

e) Projeto e constru",ção, de "' quem?

f) Além do "'mais, como tu "'sabes, gosto de soli"”dão.

Talvez tenha sido essa heterogeneidade de constituintes do período que tenha me dado um outro ponto de observação dos enunciados. Sentia aí a possibilidade de uma sintaxe do enunciado que tinha uma consistência estrutural e não apenas o caráter taxonômico e algo aleatório da distinção tradicional frase/período.

A delimitação dos segmentos pela prosódia abria esta possibilidade de se dar conta de constituintes do enunciado (período) que não coincidiam com as sentenças tradicionais. Os horizontes eram, sem dúvida, mais amplos e se configuravam numa espécie de interface prosódia/sintaxe.

Delimitados os segmentos pela prosódia, partia-se para a identificação do sol (chamado de base) e dos planetas (chamados de suplementos). 
Aqui também funcionava a prosódia. Lê-se na Gramática (BACK; MATTOS, 1972, v. I, p. 140): "Distinguimos as sentenças que são suplementos, da sentença-base pelo contorno [prosódico], que é menos variável”. Vinha em seguida a descrição dos referidos contornos.

Recortados os suplementos, partia-se para sua classificação em uma de seis classes: suplemento de apelo, de condição, de declaração, de extensão, de relato e de sequência.

Também nessa classificação havia um engenhoso jogo para não incluir critérios semânticos. Em geral, procurava-se estabelecer uma correspondência entre tipos de períodos e tipos de suplementos. Assim, por exemplo, o suplemento de condição é apresentado como tendo as seguintes características (BACK; MATTOS, 1972, v. I, p. 142):

a) corresponde ao período optativo ou ao período interrogativo ou ao decorrente de uma cláusula interrogativa (um período assertivo); b) a ordem é livre: pode ser inicial, medial ou final;

c) transformada em período composto ou em duas cláusulas, a condição passa sempre a constituir o primeiro período ou a primeira cláusula.

São exemplos de suplementos de condição:

- correspondendo ao período optativo:

"Se ele deve, deve pagar." (José Lins do Rego)

Suplemento de condição: "Se ele deve"

Teste: Ele deve?? (período optativo). Sim. (Então) deve pagar.

- correspondendo ao período interrogativo:

"Quanto às amigas, algumas datam de quinze anos." (Machado de Assis)

Suplemento de condição: "Quanto às amigas"

Teste: E quanto às amigas? (período interrogativo). Algumas datam de quinze anos

- correspondendo ao decorrente de uma cláusula interrogativa:

"Cachorro, trouxe à memória de Rubião o Quincas Borba." (Machado de Assis)

Suplemento de condição: "Cachorro" 
Teste: O que trouxe à memória de Rubião o Quincas Borba? Cachorro.

Concluindo, lembro que a Gramática Construtural nos prometia explicitamente o paraíso. Foi, por isso, duramente criticada. Contudo, até onde sei, seus pressupostos gerais e suas análises pontuais nunca foram objeto de crítica sistemática. Quando a Construtural veio a público, vivia-se já sob outros referenciais epistemológicos e ela foi descartada in limine pelo mundo acadêmico.

Posso reconhecer as fragilidades de seus pressupostos, mas posso também dizer que este modelo que combinava constituintes e uma relação de dependência, além de apoiar a segmentação sintática em fatores prosódicos, ainda hoje é, de certa forma, produtivo para mim (embora não tenha, claro, me dado o paraíso) em raciocínios práticos informais e na observação assistemática de fenômenos da língua falada.

Por isso, desprovido de qualquer fundamentalismo e já não mais praticante do trabalho analítico sistemático, guardo apenas a impressão de que os modelos com que vamos convivendo ao longo de nossa experiência de estudiosos da sintaxe da linguagem verbal, mesmo rejeitados logo à frente, vão deixando restos que não se perdem de todo.

Está aí o substrato do saber tradicional que não me deixa mentir: mesmo que de modo escamoteado, ele ainda atravessa os mais diversos olhares teóricos e insiste em não entregar os pontos.

Não se trata, obviamente, de um processo cumulativo. Trata-se, talvez, de uma rede de arquivos que não se apagam, mesmo que deletados. E, por isso, sempre acabam servindo para alguma coisa em algum momento. Afinal, como bem sabemos, o nosso objeto empírico é complexo demais.

\section{REFERÊNCIAS}

BACK, Eurico; MATTOS, Geraldo. Gramática construtural da língua portuguesa. São Paulo: Editora F.T.D., 1972. v. 1.

Submetido em: 23/05/2013

Aceito em: 12/07/2013 